\title{
Taxonomic study on the euryhaline Cyclotella (Bacillariophyta) species in Korea
}

\author{
Joon Sang Park, Sang Deuk Lee and Jin Hwan Lee* \\ Department of Life Science, Sangmyung University, Seoul 110-743, Korea
}

\begin{abstract}
Cyclotella species were collected at 51 sites from July 2010 to June 2013 in Korean coastal waters. A total of five Cyclotella species (C. atomus var. marina, C. baltica, C. litoralis, C. meduanae, and C. meneghiniana) were identified in this study. The diagnostic characteristics for five Cyclotella species are described, focusing on the spacing, position, number of satellite pores of the mantle fultoportula and valve face fultoportula. In addition, we put the salinity ranges of five species of Cyclotella together. Of the five Cyclotella species, C. baltica, C. litoralis and C. meduanae are newly recorded in Korea.
\end{abstract}

Key words: Bacillariphyceae, Cyclotella, euryhaline diatom, new to Korea

\section{INTRODUCTION}

The genus Cyclotella (Kützing) Brébisson is represented primarily in freshwater habitats, but many species, such as C. atomus Hustedt, C. baltica (Grunow) Håkansson, C. caspia Grunow, C. choctawhatcheeana Prasad, C. cryptica Reimann, Lewin et Guillard, C. desikacharyi Prasad, C. litoralis Lange et Syvertsen, C. meneghiniana Kützing, C. scaldensis Muylaert et Sabbe, C. striata (Kützing) Grunow and C. stylorum Brightwell occur in marine or brackish waters (Håkansson 2002, Prasad and Nienow 2006, Tanaka 2007).

Cyclotella are characterized by having circular valves with different ornamentation between the central area and the marginal area of the valve face. Due to the morphological similarity among species and high intra-specific variation, taxonomic discriminations of the Cyclotella species are hard to unravel (Håkansson and Kling 1994, Meyer and Håkansson 1996). In addition, further taxonomic confusion is caused by the small size of the cells and numerous similarities among the species belonging to Cyclotella sensu lato. Recently Håkansson (2002) pub- lished the genus Puncticulata Håkansson from nine $C y$ clotella species based on the central area of valve faces, as well as the particular locations of fultoportulae and rimoportulae. Houk and Klee (2004) established the genus Discostella Houk et Klee from all stelligeroid Cyclotella taxa according to the position of the mantle fultoportulae and rimoportula on marginal striae.

In Korea, Lee and Lee (1988) firstly examined six Cyclotella species from southern and western coastal waters of Korea using scanning electron microscopy. Lee et al. (1994) studied the fine structure of Cyclotella pseudostelligera Hustedt. Lee et al. (1995a) reported 15 Cyclotella species of diatoms in Korea. Lee et al. (1995b) originally described Cyclotella orientalis from the Nakdong River. Lee (1995) made a check-list and added two Cyclotella species in Korean waters. Cho (1996) founded nine Cyclotella species at Nakdong River, C. woltereckii Hustedt was firstly reported in Korea. Recently, Chung et al. (2010) first reported Cyclotella atomus var. marina from a diatom assemblage attached to an eelgrass sample at the Yeosu http://dx.doi.org/10.5141/ecoenv.2013.407

(c) $\begin{aligned} & \text { This is an Open Access article distributed under the terms of } \\ & \text { the Creative Commons Attribution Non-Commercial Licens } \\ & \text { (http://creativecommons.org/licenses/by-nc/3.0/) which }\end{aligned}$
permits unrestricted non-commercial use, distribution, and reproduction in any
medium, provided the original work is properly cited.
Received 29 October 2013, Accepted 19 November 2013

*Corresponding Author

E-mail: jhlee@smu.ac.kr Tel: +82-2-2287-5152 
Table 1. Sampling information of Cylcotella in the Korean coastal waters

\begin{tabular}{|c|c|c|c|c|}
\hline Date & Station & Locality & Latitude (N) & Longitude (E) \\
\hline 28 Aug 2010 & ${ }^{1}$ ES-01 & Dogu-ri, Donghae-myeon, Nam-gu, Pohang-si, Gyeongsangbuk-do & $35^{\circ} 59.801$ & $129^{\circ} 27.470$ \\
\hline 28 Aug 2010 & ES-02 & Duho-dong, Buk-gu, Pohang-si, Gyeongsangbuk-do & $36^{\circ} 03.812$ & $129^{\circ} 23.258$ \\
\hline 29 Aug 2010 & ES-03 & Wolpo-ri, Cheongha-myeon, Buk-gu, Pohang-si, Gyeongsangbuk-do & $36^{\circ} 12.491$ & $129^{\circ} 22.553$ \\
\hline 29 Aug 2010 & ES-04 & Ganggu-ri, Ganggu-myeon, Yeongdeok-gun, Gyeongsangbuk-do & $36^{\circ} 21.560$ & $129^{\circ} 23.141$ \\
\hline 29 Aug 2010 & ES-05 & Gusan-ri, Giseong-myeon, Uljin-gun, Gyeongsangbuk-do & $36^{\circ} 45.614$ & $129^{\circ} 28.335$ \\
\hline 29 Aug 2010 & ES-06 & Geumjin-ri, Okgye-myeon, Gangneung-si, Gangwon-do & $37^{\circ} 39.151$ & $129^{\circ} 03.107$ \\
\hline 30 Aug 2010 & ES-07 & Bongpo-ri, Toseong-myeon, Goseong-gun, Gangwon-do & $38^{\circ} 15.050$ & $128^{\circ} 34.055$ \\
\hline 30 Aug 2010 & ES-08 & Oho-ri, Jugwang-myeon, Goseong-gun, Gangwon-do & $38^{\circ} 19.474$ & $128^{\circ} 31.598$ \\
\hline 30 Aug 2010 & ES-09 & Gajin-ri, Jugwang-myeon, Goseong-gun, Gangwon-do & $38^{\circ} 22.366$ & $128^{\circ} 30.558$ \\
\hline 15 Nov 2010 & ${ }^{2}$ SS-01 & Guseong-ri, Sani-myeon, Haenam-gun, Jeollanam-do & $34^{\circ} 43.205$ & $126^{\circ} 23.178$ \\
\hline 15 Nov 2010 & SS-02 & Sin-gi-ri, Doam-myeon, Gangjin-gun, Jeollanam-do & $34^{\circ} 31.685$ & $126^{\circ} 46.390$ \\
\hline 16 Nov 2010 & SS-03 & Gyoryang-dong, Suncheon-si, Jeollanam-do & $34^{\circ} 54.535$ & $127^{\circ} 30.316$ \\
\hline 09 Jun 2011 & SS-04 & Noil-ri, Gwayeok-myeon, Goheung-gun, Jeollanam-do & $34^{\circ} 40.893$ & $127^{\circ} 19.043$ \\
\hline 10 Jun 2011 & SS-05 & Hwagye-ri, Idong-myeon, Namhae-gun, Gyeongsangnam-do & $34^{\circ} 46.528$ & $127^{\circ} 56.565$ \\
\hline 02 Nov 2012 & SS-06 & Jumun-ri, Yonghyeon-myeon, Sacheon-si, Gyeongsangnam-do & $34^{\circ} 59.530$ & $128^{\circ} 03.058$ \\
\hline 02 Nov 2012 & SS-07 & Galsa-ri, Geumseong-myeon, Hadong-gun, Gyeongsangnam-do & $34^{\circ} 56.658$ & $127^{\circ} 46.882$ \\
\hline 02 Nov 2012 & SS-08 & Annam-ri, Daeseo-myeon, Goheung-gun, Jeollanam-do & $34^{\circ} 44.881$ & $127^{\circ} 18.794$ \\
\hline $22 \mathrm{Jul} 2010$ & ${ }^{3} \mathrm{YS}-01$ & Jeongwang-dong, Siheung-si, Gyeonggi-do & $37^{\circ} 19.572$ & $126^{\circ} 39.282$ \\
\hline $22 \mathrm{Jul} 2010$ & YS-02 & Jeon-gok-ri, Seosin-myeon, Hwaseong-si, Gyeonggi-do & $37^{\circ} 11.209$ & $126^{\circ} 39.109$ \\
\hline $22 \mathrm{Jul} 2010$ & YS-03 & Gungpyeong-ri, Seosin-myeon, Hwaseong-si, Gyeonggi-do & $37^{\circ} 06.951$ & $126^{\circ} 40.618$ \\
\hline $22 \mathrm{Jul} 2010$ & YS-04 & Hanjin-ri, Songak-eup, Dangjin-si, Chungcheongnam-do & $36^{\circ} 58.248$ & $126^{\circ} 46.993$ \\
\hline $22 \mathrm{Jul} 2010$ & YS-05 & Hwagok-ri, Daesan-eup, Seosan-si, Chungcheongnam-do & $37^{\circ} 00.185$ & $126^{\circ} 27.201$ \\
\hline $23 \mathrm{Jul} 2010$ & YS-06 & Chang-ri, Buseok-myeon, Seosan-si, Chungcheongnam-do & $36^{\circ} 37.465$ & $126^{\circ} 22.003$ \\
\hline $23 \mathrm{Jul} 2010$ & YS-07 & Yeongbo-ri, Ocheon-myeon, Boryeong-si, Chungcheongnam-do & $36^{\circ} 19.689$ & $126^{\circ} 30.603$ \\
\hline $23 \mathrm{Jul} 2010$ & YS-08 & Dodun-ri, Seo-myeon, Seocheon-gun, Chungcheongnam-do & $36^{\circ} 09.481$ & $126^{\circ} 30.023$ \\
\hline $23 \mathrm{Jul} 2010$ & YS-09 & Dasa-ri, Biin-myeon, Seocheon-gun, Chungcheongnam-do & $36^{\circ} 05.867$ & $126^{\circ} 36.869$ \\
\hline $23 \mathrm{Jul} 2010$ & YS-10 & Sinchang-ri, Janghang-eup, Seocheon-gun, Chungcheongnam-do & $36^{\circ} 00.403$ & $126^{\circ} 41.874$ \\
\hline $23 \mathrm{Jul} 2010$ & YS-11 & Sutong-ri, Buri-myeon, Geumsan-gun, Chungcheongnam-do & $35^{\circ} 38.287$ & $126^{\circ} 27.771$ \\
\hline $23 \mathrm{Jul} 2010$ & YS-12 & Anseong-ri, Dongjin-myeon, Buan-gun, Jeollabuk-do & $35^{\circ} 47.250$ & $126^{\circ} 44.897$ \\
\hline $23 \mathrm{Jul} 2010$ & YS-13 & Simpo-ri, Jinbong-myeon, Gimje-si, Jeollabuk-do & $35^{\circ} 51.406$ & $126^{\circ} 41.940$ \\
\hline $24 \mathrm{Jul} 2010$ & YS-14 & Daehang-ri, Byeonsan-myeon, Buan-gun, Jeollabuk-do & $35^{\circ} 56.146$ & $126^{\circ} 31.672$ \\
\hline $24 \mathrm{Jul} 2010$ & YS-15 & Daehang-ri, Byeonsan-myeon, Buan-gun, Jeollabuk-do & $35^{\circ} 43.670$ & $126^{\circ} 31.759$ \\
\hline $24 \mathrm{Jul} 2010$ & YS-16 & Daehang-ri, Byeonsan-myeon, Buan-gun, Jeollabuk-do & $35^{\circ} 41.283$ & $126^{\circ} 31.922$ \\
\hline $24 \mathrm{Jul} 2010$ & YS-17 & Sinsido-ri, Okdo-myeon, Gunsan-si, Jeollabuk-do & $35^{\circ} 43.732$ & $126^{\circ} 31.916$ \\
\hline 14 Oct 2010 & YS-18 & Wolgot-dong, Siheung-si, Gyeonggi-do & $37^{\circ} 23.247$ & $126^{\circ} 44.413$ \\
\hline 14 Oct 2010 & YS-19 & Jeongwang-dong, Siheung-si, Gyeonggi-do & $37^{\circ} 20.725$ & $126^{\circ} 41.265$ \\
\hline 14 Oct 2010 & YS-20 & Sa 2-dong, Sangrok-gu, Ansan-si, Gyeonggi-do & $37^{\circ} 17.509$ & $126^{\circ} 49.289$ \\
\hline 14 Oct 2010 & YS-21 & Manho-ri, Poseung-eup, Pyeongtaek-si, Gyeonggi-do & $36^{\circ} 57.666$ & $126^{\circ} 50.000$ \\
\hline 14 Oct 2010 & YS-22 & Gwongwan-ri, Hyeondeok-myeon, Pyeongtaek-si, Gyeonggi-do & $36^{\circ} 55.031$ & $126^{\circ} 54.394$ \\
\hline 14 Oct 2010 & YS-23 & Daeeum-ri, Inju-myeon, Asan-si, Chungcheongnam-do & $36^{\circ} 51.157$ & $126^{\circ} 51.278$ \\
\hline 14 Oct 2010 & YS-24 & Unjeong-ri, Sinpyeong-myeon, Dangjin-si, Chungcheongnam-do & $36^{\circ} 53.385$ & $126^{\circ} 49.573$ \\
\hline 14 Oct 2010 & YS-25 & Seopo-ri, Napo-myeon, Gunsan-si, Jeollabuk-do & $36^{\circ} 02.165$ & $126^{\circ} 47.043$ \\
\hline 14 Oct 2010 & YS-26 & Soryong-dong, Gunsan-si, Jeollabuk-do & $35^{\circ} 58.019$ & $126^{\circ} 37.032$ \\
\hline 15 Oct 2010 & YS-27 & Seonyeon-ri, Okseo-myeon, Gunsan-si, Jeollabuk-do & $35^{\circ} 53.158$ & $126^{\circ} 37.737$ \\
\hline 15 Oct 2010 & YS-28 & Woryeon-ri, Hoehyeon-myeon, Gunsan-si, Jeollabuk-do & $35^{\circ} 53.180$ & $126^{\circ} 43.653$ \\
\hline 15 Oct 2010 & YS-29 & Geumgwang-ri, Hoehyeon-myeon, Gunsan-si, Jeollabuk-do & $35^{\circ} 53.351$ & $126^{\circ} 46.013$ \\
\hline 15 Oct 2010 & YS-30 & Anseong-ri, Dongjin-myeon, Buan-gun, Jeollabuk-do & $35^{\circ} 47.238$ & $126^{\circ} 44.822$ \\
\hline 15 Oct 2010 & YS-31 & Gyehwa-ri, Gyehwa-myeon, Buan-gun, Jeollabuk-do & $35^{\circ} 47.634$ & $126^{\circ} 38.629$ \\
\hline 15 Nov 2010 & YS-32 & Ogam-dong, Mokpo-si, Jeollanam-do & $34^{\circ} 47.803$ & $126^{\circ} 26.097$ \\
\hline 15 Apr 2011 & YS-33 & Busu-ri, Sinpyeong-myeon, Dangjin-si, Chungcheongnam-do & $36^{\circ} 54.605$ & $126^{\circ} 48.900$ \\
\hline 17 Apr 2011 & YS-34 & Gung-ri, Seobu-myeon, Hongseong-gun, Chungcheongnam-do & $36^{\circ} 35.608$ & $126^{\circ} 27.347$ \\
\hline
\end{tabular}

${ }^{1} \mathrm{ES}$, East Sea; ${ }^{2} \mathrm{SS}$, South Sea; ${ }^{3} \mathrm{YS}$, Yellow Sea. 
coast in Korea.

Although 21 species of Cyclotella diatom have been recorded in Korea (Lee et al. 1995a, Lee 1995, Cho 1996, Chung et al. 2010), several Cyclotella species have been transferred into the other cyclotelloid genera, such as Discostella and Puncticulata, following the recent complication of cyclotelloid diatoms (Håkansson 2002, Houk and Klee 2004): four Cyclotella species (C. bodanica Eulenstein, C. comta (Ehrenberg) Kützing, C. comta var. glabriuscula Grunow, C. radiosa (Grunow) Lemmermann) were transferred into the genus Puncticulata; five Cyclotella species (C. comta var. glabriuscula Grunow, C. orientalis Lee, Chung et Gotoh, C. pseudostelligera Hustedt, C. stelligera (Cleve et Grunow) Van Heurck, C. woltereckii Hustedt) were transferred into the genus Discostella.

We present the fine structure, description, distribution and taxonomic remarks of five Cyclotella species in Korean waters. Of the five species discussed in this paper, we include three species which are newly recorded in Korea.

\section{MATERIALS AND METHODS}

Sample collections were carried out at 51 sites from July 2010 to June 2013 in Korean coastal waters (Table 1). Phytoplankton were collected using a $20 \mu \mathrm{m}$ mesh net by horizontal and/or vertical towing. Samples were immediately fixed with neutralized formalin (5\% final concentration). Using a method presented by Hasle and Fryxell (1970), organic matter in the diatom cell was removed. Prepared diatom material was observed under a light microscope (Axioskop 40; Carl Zeiss, Oberkochen, Germany) and a scanning electron microscope (JSM-5600LV; JEOL, Tokyo, Japan), and was photographed with an MRc5 camera (Carl Zeiss). Diatom size analysis was completed with image calculation software (AxioVision AC version 4.5; Carl Zeiss). The general terminology was adopted from the proposals on Diatom Terminology (Anonymous 1975, Ross et al. 1979), and some special terms for Cyclotella followed Håkansson (2002) and Tanaka (2007).

\section{RESULTS AND DISCUSSION}

A total of five Cyclotella were identified in the present study, we present keys for five Cyclotella species based on morphological characteristics, such as the space, position, number of satellite pores of the mantle fultoportula and valve face fultoportula (Table 2).

\section{Key to 5 Cyclotella species in Korea}

1a. Two satellite pores on mantle fultoportula .2

1b. Three satellite pores on mantle fultoportula ................4

2a. No central fultoportula ............... . atomus var. marina

2b. Several central fultoportula ............................................

3a. Mantle fultoportula on recessed interstria ...C. litoralis 3b. Mantle fultoportula on thickened interstria...C. baltica 4a. Space of mantle fultoportula on every 2 nd interstria .C. meduanae

4b. Space of mantle fultoportula on every interstria C. meneghiniana

\section{Description of species}

Cyclotella atomus var. marina Tanimura, Nagumo et Kato 2004 (Fig. 1)

Description: Valves are 2.8-5.0 $\mu \mathrm{m}$ in diameter. The central area is flat to slightly tangentially undulate without colliculate ornamentation (Fig. 1A and 1B). The marginal striae density is $20-25$ in $10 \mu \mathrm{m}$. Valve face fultoportula is absent. Mantle fultoportulae located on every 2nd to 3rd interstria (Fig. 1A-1D), internally the tubulus is surrounded by two satellite pores (Fig.1C and 1D). A single rimoportula located on the ring of mantle fultoportulae, internally the rimoportula has a narrow sessile labium (Fig. 1C and 1D).

Distribution: Cyclotella atomus var. marina was found from a diatom assemblage attached to an eelgrass sample taken from waters with a salinity of approximately 26, in the region of Yulimri, Yeosu City, Korea in July 1998 (Chung et al. 2010). However, the species occurred total 5 times as a planktonic in this study and reported once and four times from the South Sea and the Yellow Sea, respectively (Table 3).

Remarks: Cyclotella atomus var. marina is distinguished from other variety of C. atomus by the absence of a valve face fultoportula (Chung et al. 2010).

\section{Cyclotella baltica (Grunow) Håkansson 2002 (Fig. 2)}

Basionym: Cyclotella striata var. baltica Grunow in Van Heurck 1882, pl. 92, figs 13-15, non Cyclotella litoralis Lange et Syvertsen sensu Håkansson 1996.

Description: Valves are 13.9-37.0 $\mu \mathrm{m}$ in diameter. The central area tangentially undulate with a slightly colliculate ornamentation (Fig. 2A-2C and 2E). The marginal striae density is $10-15$ in $10 \mu \mathrm{m}$. Valve face fultoportula number two to nine (Fig. 2C-2F), internally surrounded by three satellite pores (Fig. 2D and 2F). Mantle fultoportulae located on every 2nd to 3rd interstria (Fig. 2G and 


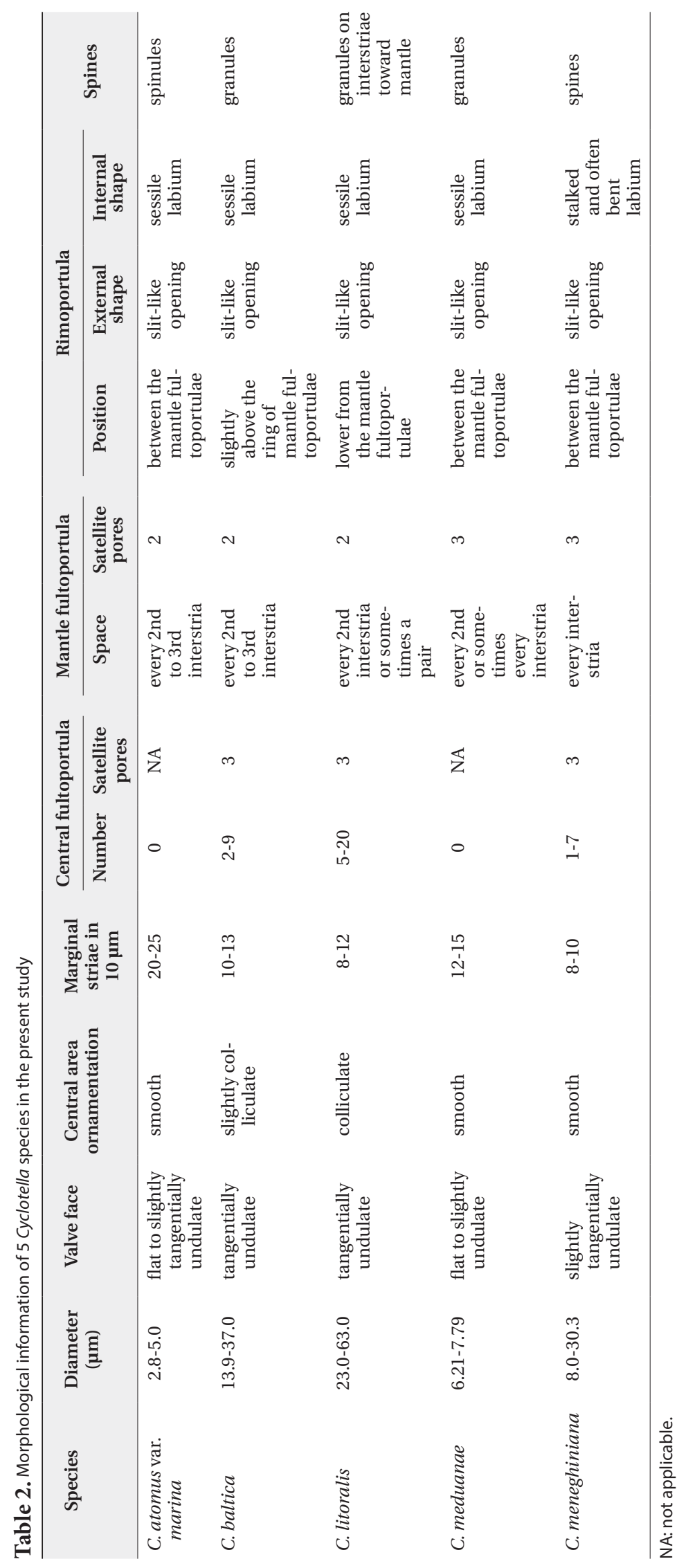



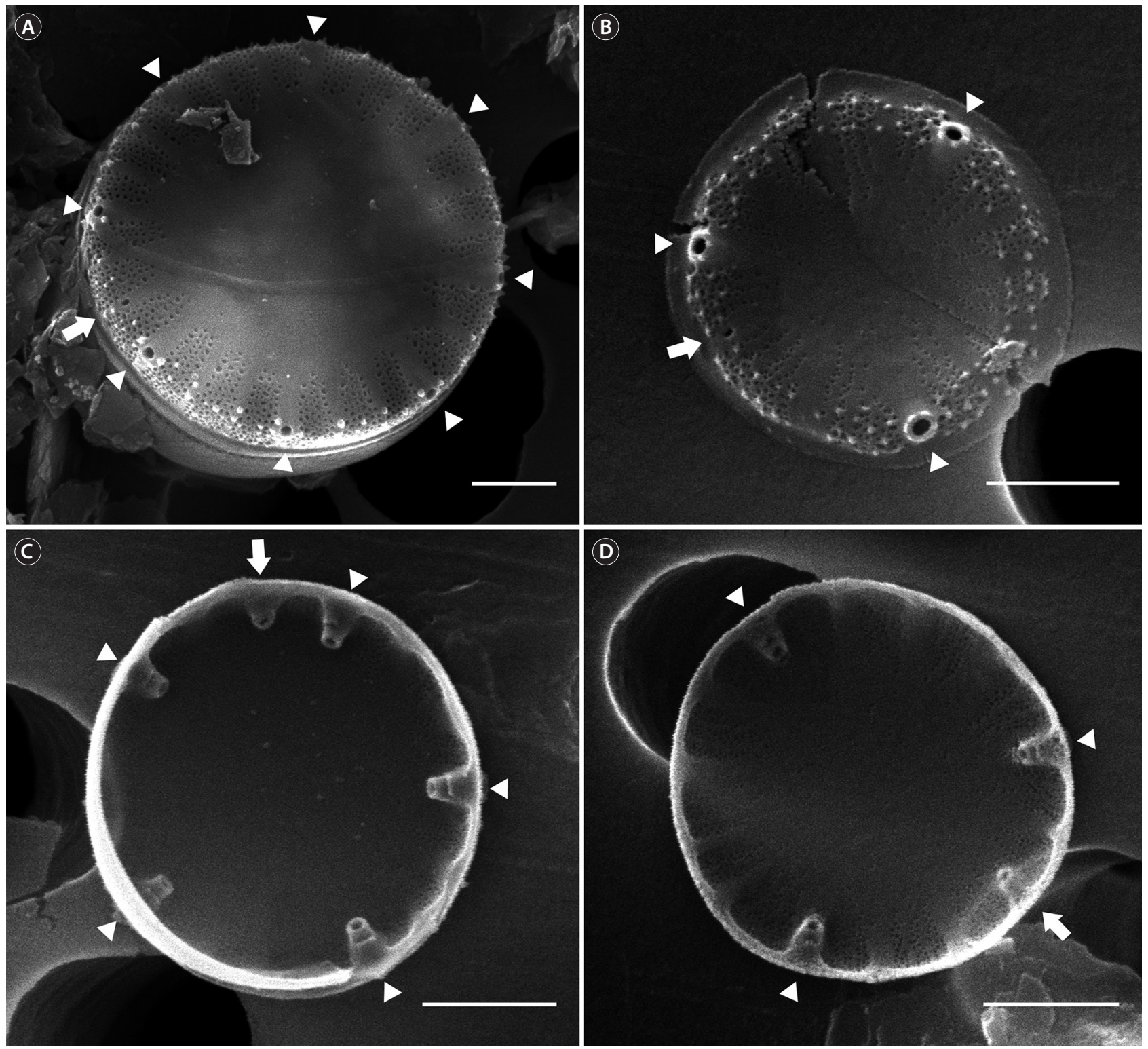

Fig. 1. Cyclotella atomus var. marina Tanimura, Nagumo et Kato. Arrow and arrowheads indicate the rimoportula and the fultoportula respectively. (A-B) External valve view, (C-D) Internal valve view. Scale bars, $1 \mu \mathrm{m}$.

$2 \mathrm{H}$ ), internally the tubulus is surrounded by two satellite pores (Fig. 2H). A single rimoportula located slightly above the ring of the mantle fultoportulae, internally the rimoportula has a sessile labium (Fig. $2 \mathrm{H}$ ).

Distribution: Grunow (1882) collected C. baltica from the Baltic. Tanaka (2007) collected this species from Hokkaido to Kyushu in Lake Abshiri, Mikawa Bay, and regarded as a brackish to marine water species. Cyclotella baltica occurred total 11 times in this study, and was observed as a planktonic from the East Sea (one time) and the Yellow Sea (10 times), there was no occurrence from the South
Sea (Table 3). This species is firstly recorded in the present study.

Remarks: Håkansson (2002) placed C. striata var. baltica in C. baltica according to the absence of the valve face fultoportula, and stated that the species were regarded as C. striata previously (Hustedt 1928, Cleve-Euler 1951, Helmcke and Krieger 1954, Helmcke et al. 1974, Takano 1976, Prasad et al. 1990) was in fact C. baltica. Tanaka (2007) described C. baltica from Japanese specimens. However, the Japanese material showed some differences from the lectotype of Håkansson (2002): a valve diameter 


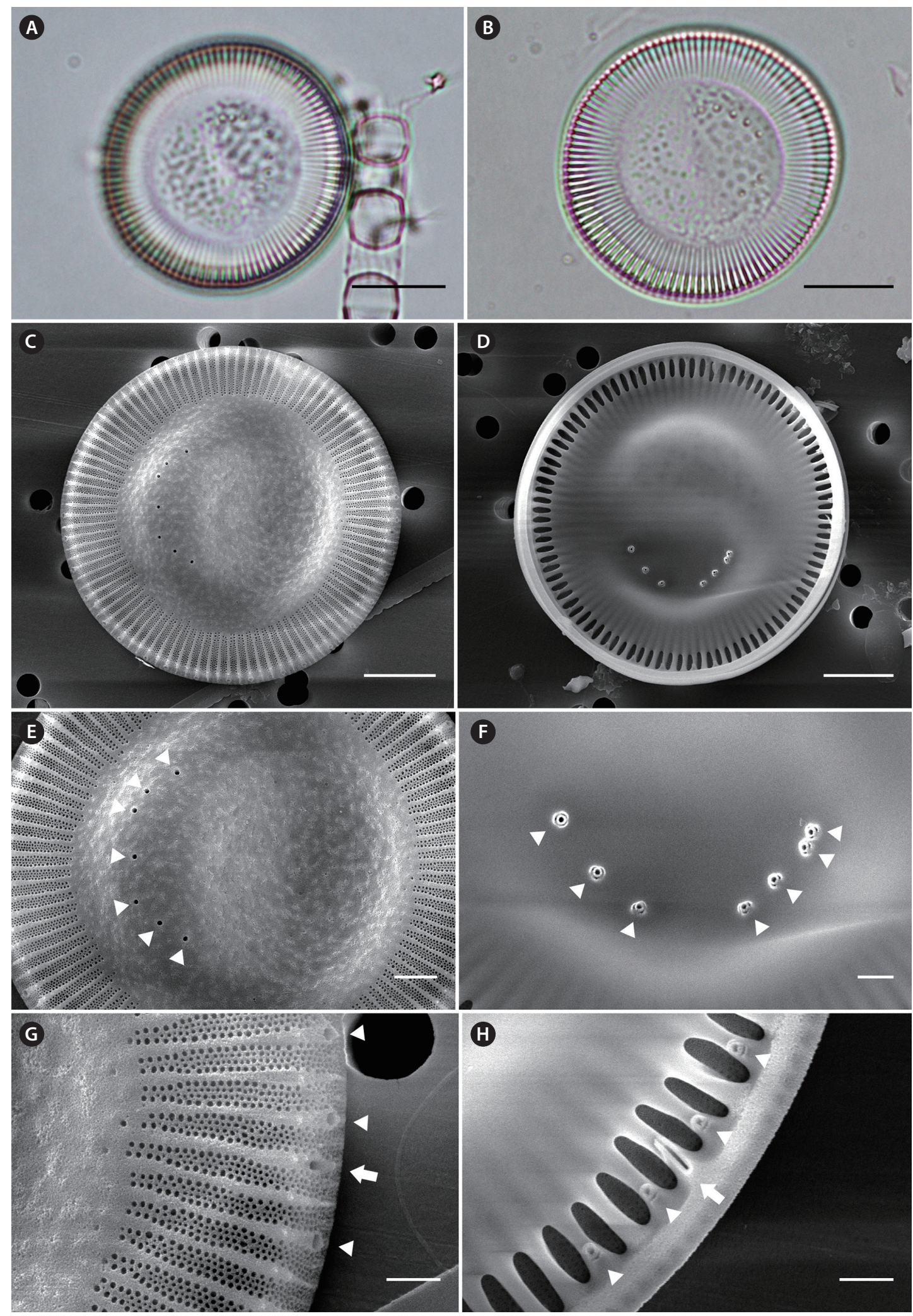

Fig. 2. Cyclotella baltica (Grunow) Håkansson. Arrow and arrowheads indicate the rimoportula and the fultoportula, respectively. (A) External valve view, (B) Internal valve view, (C) Central area with 7 fultoportulae in the external valve view, (D) Seven fultoportulae with 3 satellite pores on the central area of valve face in the internal valve view, (E) Externally striated marginal area with mantle fultoportulae and rimoportula, (F) Internally alveolated marginal area with mantle fultoportulae and rimoportula. Scale bars represent: $A, B, 10 \mu \mathrm{m} ; \mathrm{C}, \mathrm{D}, 5 \mu \mathrm{m} ; \mathrm{E}, 2 \mu \mathrm{m} ; \mathrm{G}, \mathrm{H}, 1 \mu \mathrm{m}$. 
Table 3. Check-list of 5 Cyclotella species in Korean coastal waters

\begin{tabular}{|c|c|c|c|c|c|c|c|}
\hline Sea & Station & Salinity (psu) & C. atomus var. marina & C. baltica & C. litoralis & C. meduanae & C. meneghiniana \\
\hline \multirow[t]{9}{*}{ East Sea } & ES-01 & 33.45 & & & & & + \\
\hline & ES-02 & 29.88 & & & & & + \\
\hline & ES-03 & 33.71 & & & & & + \\
\hline & ES-04 & 33.57 & & & & & + \\
\hline & ES-05 & 33.95 & & & + & & + \\
\hline & ES-06 & 32.36 & & & & & + \\
\hline & ES-07 & 31.73 & & + & & & \\
\hline & ES-08 & 26.72 & & & & & + \\
\hline & ES-09 & 27.84 & & & & & + \\
\hline \multirow[t]{9}{*}{ South Sea } & SS-01 & 1.90 & & & & & + \\
\hline & SS-02 & 30.87 & & & + & & \\
\hline & SS-03 & 0.04 & & & & & + \\
\hline & SS-04 & 34.80 & & & + & & \\
\hline & SS-05 & 29.79 & & & + & & \\
\hline & SS-06 & 28.01 & + & & + & & \\
\hline & SS-07 & 28.88 & & & + & & \\
\hline & SS-08 & 27.37 & & & & & \\
\hline & SS-09 & 30.88 & & & + & & \\
\hline \multirow[t]{34}{*}{ Yellow Sea } & YS-01 & 30.13 & & + & + & & + \\
\hline & YS-02 & 21.50 & & & + & & \\
\hline & YS-03 & 27.80 & & & + & & \\
\hline & YS-04 & 29.31 & & & + & & \\
\hline & YS-05 & 31.32 & & & + & & \\
\hline & YS-06 & 15.93 & & & + & & + \\
\hline & YS-07 & 31.17 & & & + & & \\
\hline & YS-08 & 30.61 & & + & + & & \\
\hline & YS-09 & 27.25 & & & + & & \\
\hline & YS-10 & 23.05 & & & & & + \\
\hline & YS-11 & 30.68 & & & + & & \\
\hline & YS-12 & 10.17 & + & + & & + & + \\
\hline & YS-13 & 16.55 & & + & & & + \\
\hline & YS-14 & 29.84 & & + & & & + \\
\hline & YS-15 & 29.66 & & & + & & \\
\hline & YS-16 & 29.79 & & & + & & \\
\hline & YS-17 & 28.54 & & & + & & \\
\hline & YS-18 & 24.56 & & & + & & + \\
\hline & YS-19 & 26.43 & & & + & & \\
\hline & YS-20 & 19.73 & + & & & & + \\
\hline & YS-21 & 26.04 & & & + & & + \\
\hline & YS-22 & 23.22 & & & + & & + \\
\hline & YS-23 & 0.20 & & & & & + \\
\hline & YS-24 & 23.98 & & & + & & \\
\hline & YS-25 & 0.10 & & & & & + \\
\hline & YS-26 & 18.78 & & & & & + \\
\hline & YS-27 & 21.88 & + & + & & & + \\
\hline & YS-28 & 22.70 & + & + & + & + & + \\
\hline & YS-29 & 13.20 & & + & & + & + \\
\hline & YS-30 & 15.32 & & + & + & & + \\
\hline & YS-31 & 26.27 & & + & + & & + \\
\hline & YS-32 & 30.80 & & & & & + \\
\hline & YS-33 & 23.77 & & & & & + \\
\hline & YS-34 & 33.97 & & & + & & \\
\hline \multicolumn{3}{|c|}{ Total occurences } & 5 & 11 & 29 & 3 & 30 \\
\hline
\end{tabular}


and the position of external opening of rimoportula. The morphological characteristics in Korean specimens agree with the description of C. baltica in Håkansson (2002): a valve diameter, the external position of rimoportula, the striae dense and the spacing of mantle fultoportulae. Although Korean specimens show well-developed alveoli in the internal valve view (Fig. $2 \mathrm{~B}$ and $2 \mathrm{~F}$ ), the variation of alveoli development within Cyclotella species have been reported (Beszteri et al. 2005). Therefore, we regarded the Korean specimens as C. baltica.

\section{Cyclotella litoralis Lange et Syvertsen 1989 (Fig. 3)}

Description: Valves are 23.0-63.0 $\mu \mathrm{m}$ in diameter. The central area tangentially undulates with colliculate ornamentation (Fig. 3A-3C and 3E). The marginal striae density is 8-12 in $10 \mu \mathrm{m}$. Valve face fultoportula is eight to twelve (Fig. 3C and 3D), internally surrounded by three satellite pores (Fig. 3F). Mantle fultoportulae located on every 2nd (Fig. 3G and 3H), or sometimes, on a pair (Fig. $3 \mathrm{G})$, internally the tubulus is surrounded by two satellite pores (Fig. 3H). A single rimoportula is located on the fultoportulae below the mantle, internally the rimoportula has a sessile labium (Fig. 3H).

Distribution: Lange and Syvertsen (1989) originally described as C. litoralis from the south western Atlantic, and Tanaka (2007) described this species in Isahaya Bay, Nagasaki Prefecture, Japan. This species was observed 29 times from all of the Sea as a planktonic in this study (Table 3). Although C. litoralis is firstly recorded in this study, Lee and Lee (1988) already observed Cyclotella sp. A from Gwangyang Bay and Jinhae Bay. However, since then there was no additional study for identification of the species.

Remarks: Cyclotella litoralis have been confused with C. striata complex (e.g., C. baltica, C. striata, C. stylorum): This species have been distinguished from C. baltica based on the spacing of the mantle fultoportulae (Håkansson 2002), as well as the number of central fultoportula (Prasad and Nienow 2006). In this study, the presence of the recessed costa is an additional characteristic for distinguishing between the two species (Fig 2B and 3B). $C y$ clotella striata can be distinguished from $C$. litoralis based on the absence of a valve face fultoportula (Håkansson 2002). The spacing of mantle fultoportula can be used to distinguish between C. litoralis and C. stylorum (Lange and Syvertsen 1989).

\section{Cyclotella meduanae Germain 1981 (Fig. 4)}

Description: Valves are 6.2-7.8 $\mu \mathrm{m}$ in diameter. The central area is flat to slightly tangentially undulate, without colliculate ornamentation (Fig. 4A and 4B). The marginal striae density is $12-15$ in $10 \mu \mathrm{m}$. Valve face fultoportula is absent (Fig. 4A-4C). Marginal fultoportulae are located on every 2 nd to 3rd interstria (Fig. 4A-4D), internally the tubulus is surrounded by three satellite pores (Fig. 4D). A single rimoportula is located on the ring of marginal fultoportulae, internally the rimoportula has a narrow sessile labium (Fig. 4D).

Distribution: Cyclotella meduanae originally described from Mayenne, France (Germain 1981). Tanaka (2007) examined the Japanese specimen from Inba Pond, Chiba Prefecture and mentioned that $C$. meduanae has been found mainly in eutrophic water and freshwater. In the present study, C. meduanae is newly recorded and was found 3 times as a planktonic (Table 3 ).

Remarks: Cyclotella meduanae has been noted to have morphological similarity with C. meneghiniana (Håkansson 2002). Håkansson (2002) mentioned that the only difference between both species is the absence or presence of the valve face fultoportula. However, we found an additional difference in the spacing of the mantle fultoportulae between C. meduanae and C. meneghiniana: in the first one, the mantle fultoportulae was located on every second interstria, while the latter on every interstria (compare Fig. 4C with Fig. 5B).

\section{Cyclotella meneghiniana Kützing 1844 (Fig. 5)}

Synonyms: Surirella melosiroides G.G.A. Meneghini ms. 1844; Cyclotella kuetzingiana var. meneghiniana (Kützing) Brun 1880; Stephanocyclus meneghiniana (Kützing) Skabichevskii 1975.

Description: Valves are 8.0-30.3 $\mu \mathrm{m}$ in diameter. The central area is slightly tangentially undulate and without colliculate ornamentation (Fig 5A-5E). The marginal striae density is $8-10$ in $10 \mu \mathrm{m}$. Valve face fultoportula is one to seven (Fig. 5A-5F), internally surrounded by three satellite pores (Fig. 5F). Marginal fultoportulae are located on every interstria (Fig. $5 \mathrm{G}$ and $5 \mathrm{H}$ ), internally the tubulus is surrounded by three satellite pores (Fig. 5H). A single rimoportula located on the ring of marginal fultoportulae, internally the rimoportula has a stalked, and often bent, sessile labium (Fig. 5H).

Distribution: Cyclotella meneghiniana have been found in varied habitats including brackish water, and both eutrophic and oligotrophic freshwater (Håkansson 2002, Tanaka 2007). In Korea, Lee and Lee (1988) firstly recorded C. meneghiniana in the Han River and Ulsan Bay near Taehwa River estuary. Cho (1996) described C. meneghiniana from the Nakdong River. Cyclotella meneghiniana was most frequently observed in this study. This species 

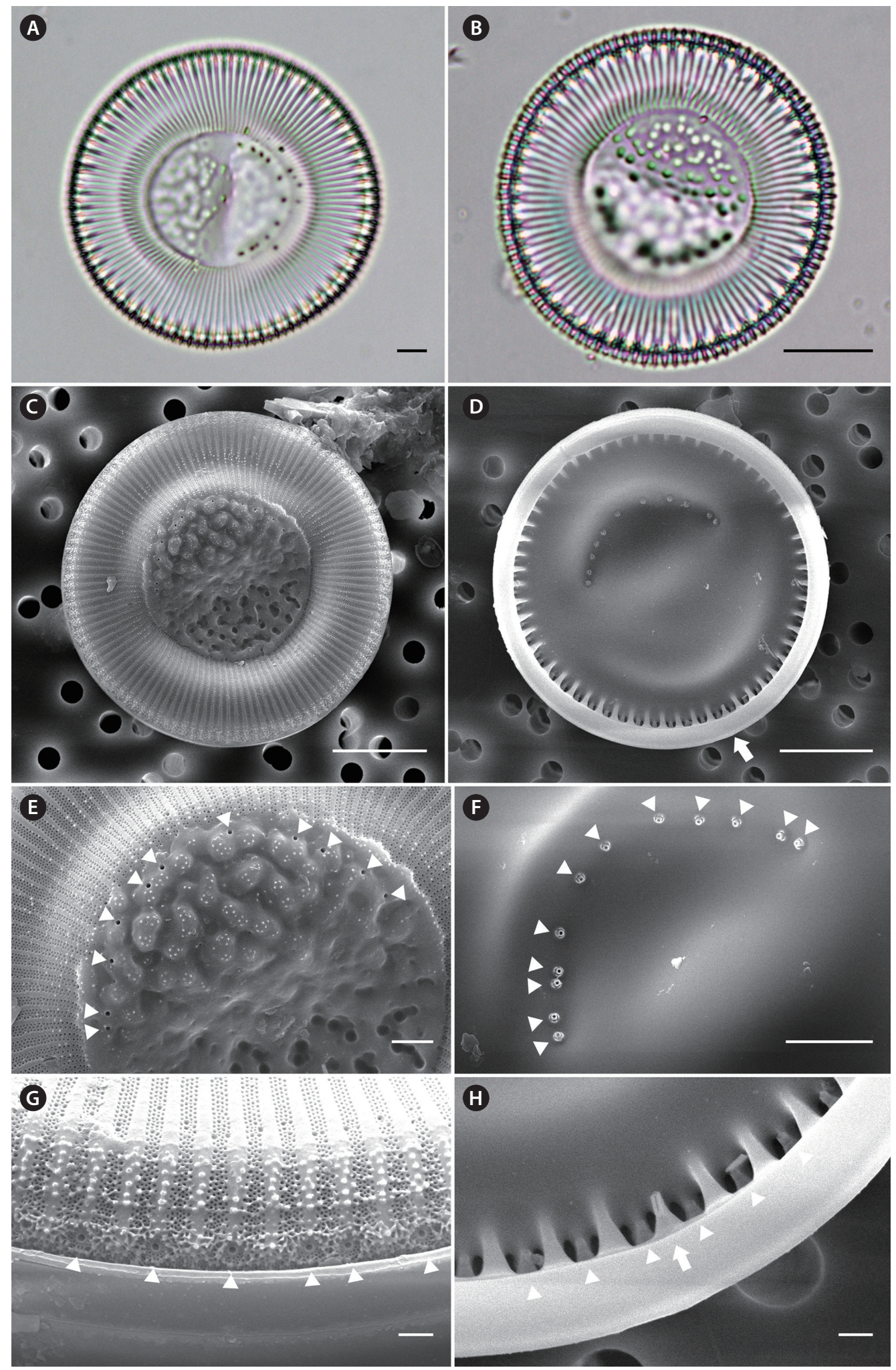

Fig. 3. Cyclotella litoralis Lange et Syvertsen. Arrow indicates the rimoportula. (A) External valve view, (B) Internal valve view, (C) Central area with 10 fultoportulae (arrowheads) in the external valve view, (D) Twelve fultoportulae (arrowheads) with 3 satellite pores on the central area of valve face in the internal valve view, (E) Externally striated marginal area with mantle fultoportulae (arrowheads) and rimoportula, (F) Internally marginal area with mantle fultoportulae (arrowheads) on the recessed interstria and a sessile rimoportula between two fultoportulae. Scale bars represent: A-D, $10 \mu \mathrm{m} ; \mathrm{E}, 1 \mu \mathrm{m} ; \mathrm{F}, 5$ $\mu \mathrm{m} ; \mathrm{G}, \mathrm{H}, 1 \mu \mathrm{m}$. 

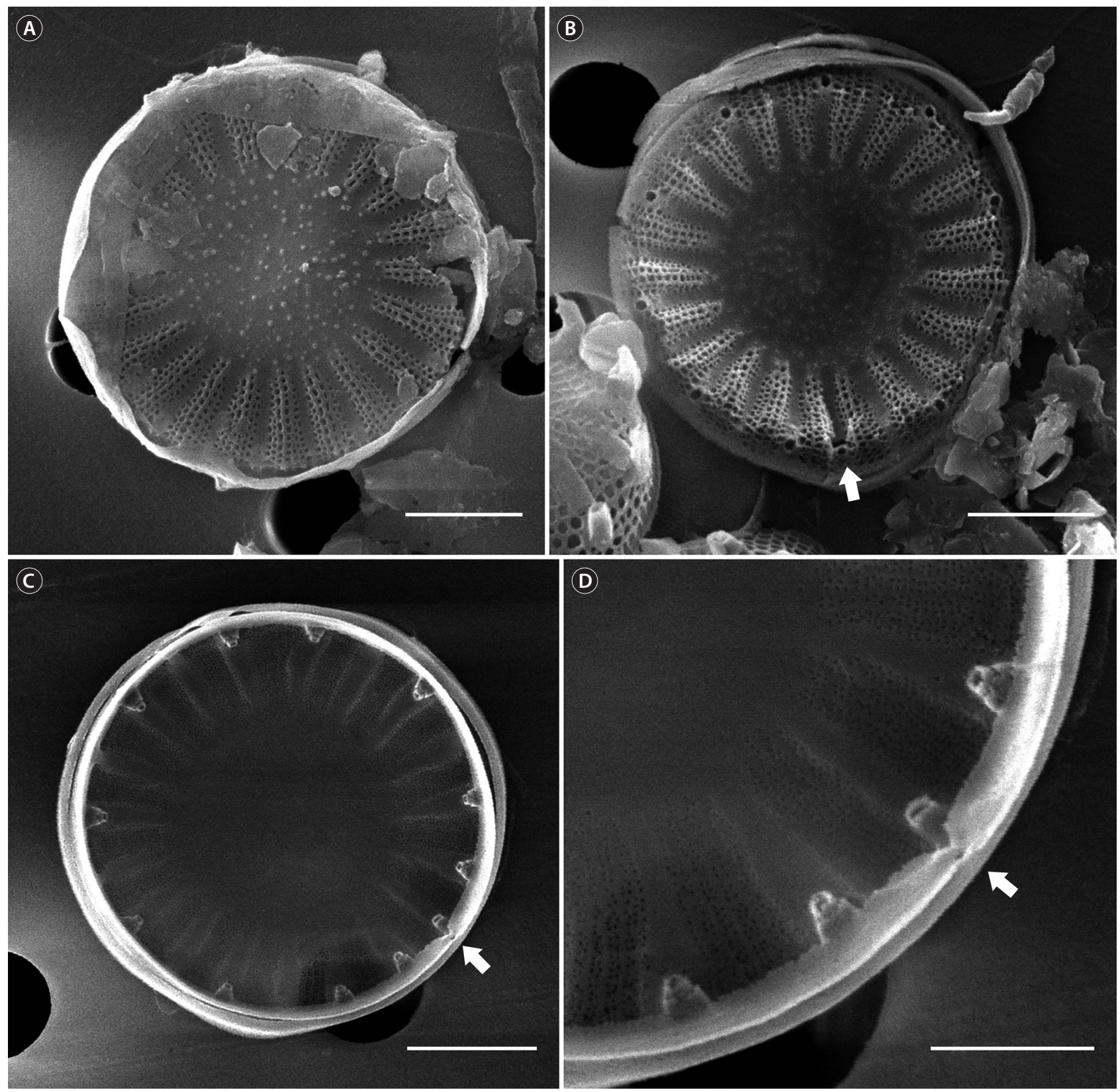

Fig. 4. Cyclotella meduanae Germain. Arrow indicates the rimoportula. (A-B) External valve view, (C) Internal valve view, (D) Internal mantle fultoportulae on every interstria and sessile rimoportula between two mantle fultoportulae. Scale bars represent: A-C, $2 \mu \mathrm{m} ; \mathrm{D}, 1 \mu \mathrm{m}$.

was reported total 30 times in this study, 8 times from the East Sea, 2 times from the South Sea, and 20 times from the Yellow Sea as a planktonic (Table 3).

Remarks: Cyclotella meneghiniana has been known to have a wide ecological distribution (Håkansson 2002, Finlay et al. 2002), and highly variable frustule (Håkansson and Chepurnov 1999).

Therefore, this species has been confused with several Cyclotella species such as C. ceylonica Holsinger, C. pratii
Toman, C. kuetzingiana Thwaites (Håkansson 2002). Recently, Beszteri et al. (2007) investigated the cryptic diversity of C. meneghiniana based on nuclear and plastid genes. Although this study did not analyze the molecular sequences, it is needed to understand the cryptic diversity of C. meneghiniana in Korea.

Occurrence of Cyclotella species according to the salinity This study present the salinity range of five Cyclotella 


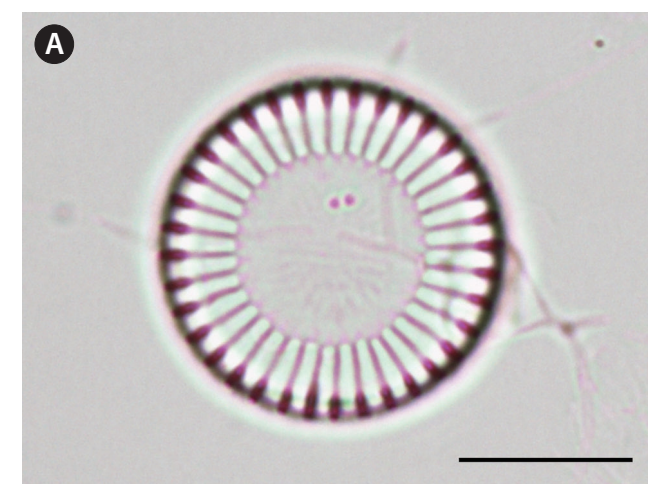

B
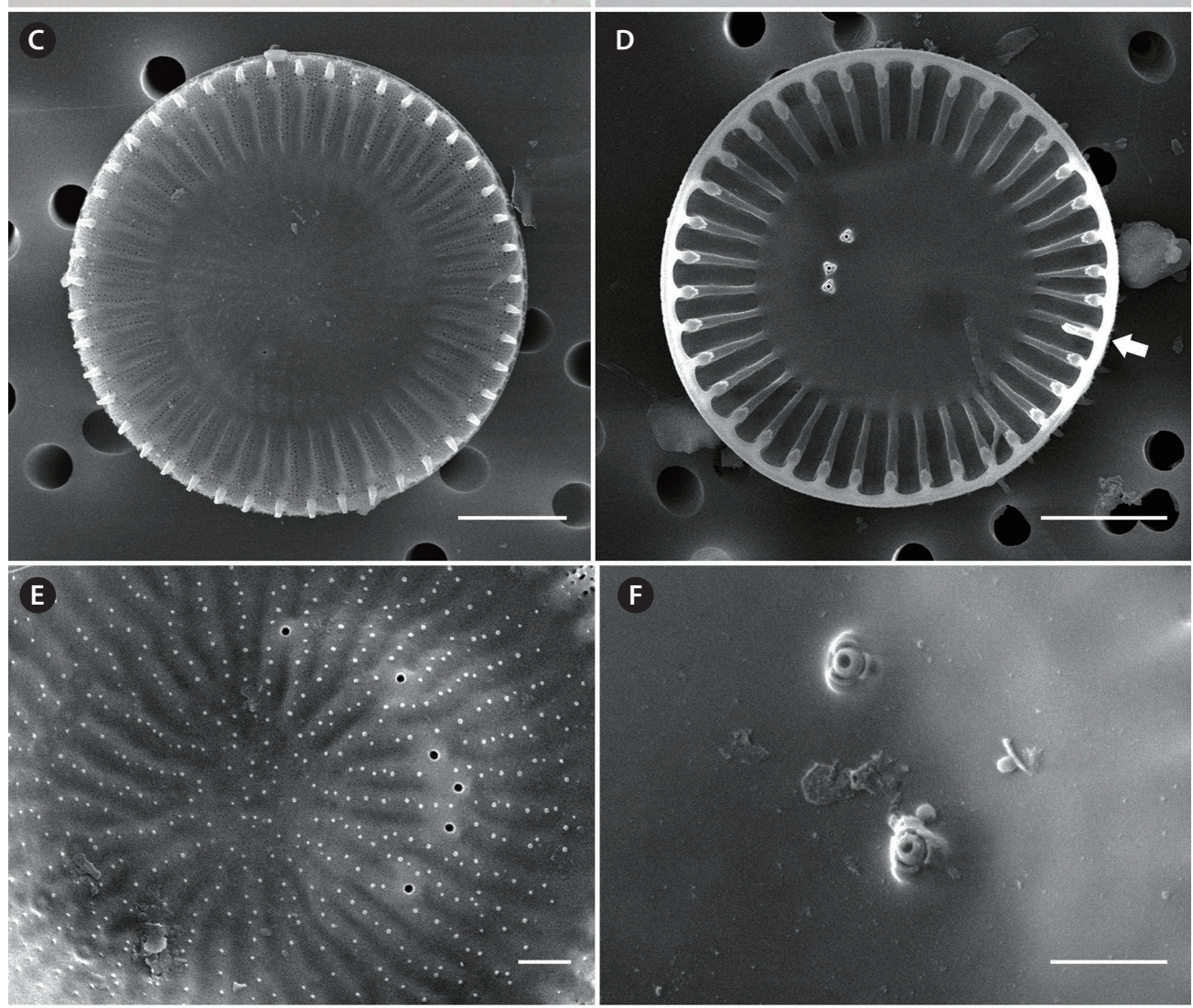

F
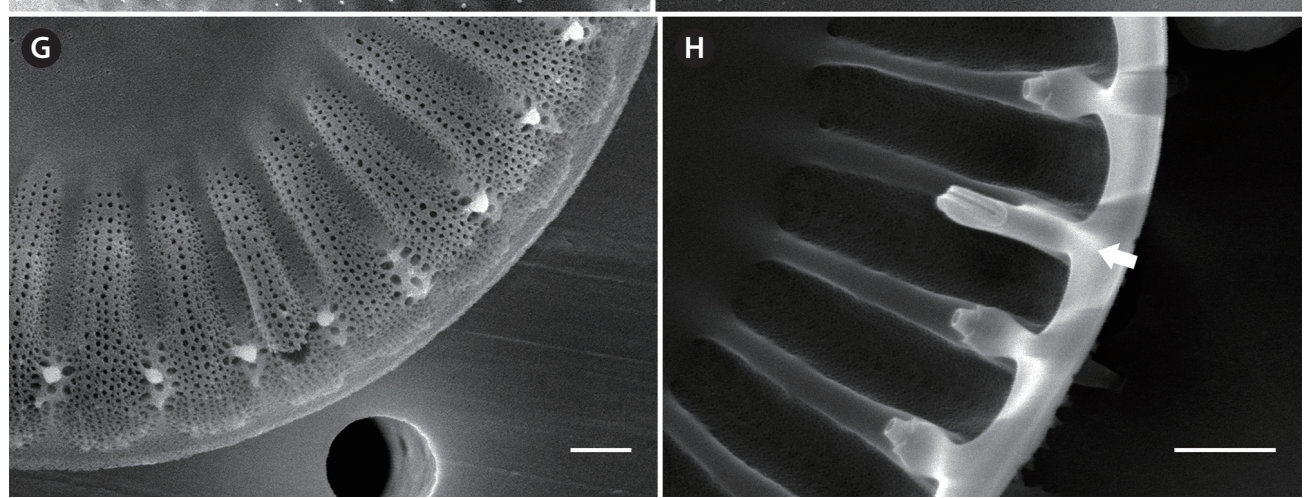

Fig. 5. Cyclotella meneghiniana Kützing. Arrow indicates the rimoportula. (A) External valve view, (B) Internal valve view, (C) Central area with 6 fultoportulae in the external valve view, (D) Two fultoportulae with 3 satellite pores on the central area of valve face in the internal valve view, (E) Externally striated marginal area with mantle fultoportulae, (F) Internally marginal area with mantle fultoportulae on the interstria and a sessile rimoportula between two fultoportulae. Scale bars represent: A, B, $10 \mu \mathrm{m} ; \mathrm{C}, \mathrm{D}, 5 \mu \mathrm{m} ; \mathrm{E}-\mathrm{H}, 1 \mu \mathrm{m}$. 


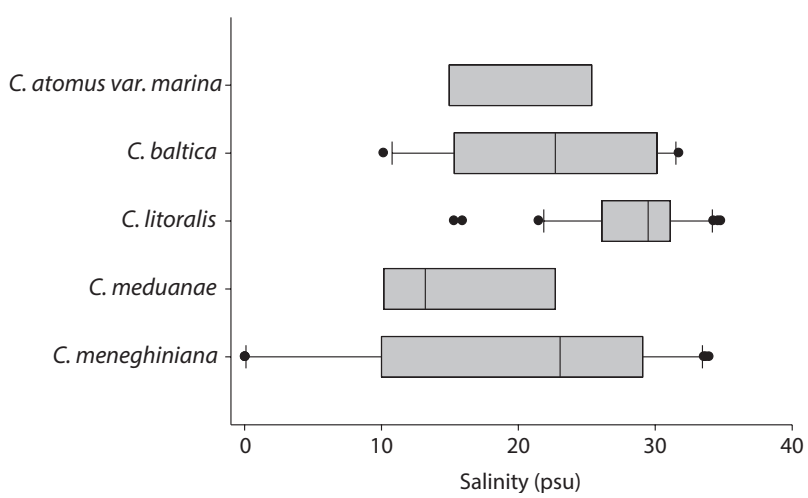

Fig. 6. Box plot of data of salinity range from five Cyclotella species in Korea.

species in the Korean coastal waters (Fig. 6). Cyclotella atomus var. marina occurred in a range of 10.17-28.01 psu from five sites; C. baltica was collected at 11 sites in a range of 10.17-31.73 psu; C. litoralis was reported in a range of 15.32-34.80 psu at 29 sites; C. meduanae have a salinity range of 10.17-22.70 psu from 3 sites; C. meneghiniana occurred in a range of 0.04-34.95 psu from 30 sites. Most of species occur a wide range of 10-30 psu, which indicate the leakage of Cyclotella species into the coastal waters may be more diverse than previous consideration. (Round and Sims 1980).

\section{ACKNOWLEDGMENTS}

This work was supported by a grant from the National Institute of Biological Resources (NIBR), as funded by the Ministry of Environment (MOE) of Republic of Korea (NIBR No. 2013-01-001), and by a 2013 Research Grant from Sangmyung Universtiy.

\section{LITERATURE CITED}

Anonymous. 1975. Proposals for a standardization of diatom terminology and diagnoses. Nova Hedwig Beiheft 53: 323-354.

Beszteri B, Ács E, Medlin L. 2005. Conventional and geometric morphometric studies of valve ultrastructural variation in two closely related Cyclotella species (Bacillariophyta). Eur J Phycol 40: 89-103.

Beszteri B, John U, Medlin LK. 2007. An assessment of cryptic genetic diversity within the Cyclotella meneghiniana species complex (Bacillariophyta) based on nuclear and plastid genes, and amplified fragment length polymor- phisms. Eur J Phycol 42: 47-60.

Cho KJ. 1996. Fine morphology of some Cyclotella species from the freshwater zone of the Nakdong River. Algae 11: 9-21.

Chung MH, Yoon WD, Lee J-B. 2010. Morphological description of Cyclotella atomus var. marina (Bacillariophyceae): newly reported in Korean waters. Algae 25: 57-64.

Cleve-Euler A. 1951. Die Diatomeen von Schweden und Finnland. Band I, Centricae. Kungliga Svenska Vetenskapsakademien Handlingar, Ser 4. Vol 2. Royal Swedish Academy of Sciences, Stockholm.

Finlay BJ, Monaghan EB, Maberly SC. 2002. Hypothesis: the rate and scale of dispersal of freshwater diatom species is a function of their global abundance. Protist 153: 261273.

Germain H. 1981. Flore des Diatomées - Diatomophycées - eaux douces et saumâtres du Massif Armoricain et des contrées voisines d'Europe occidentale. Collection "Faunes et Flores Actuelles". Société Nouvelle des Editions Boubée, Paris.eaux douces et saumâtres. Société nouvelle des éditions Boubée, Paris.

Grunow A. 1882. Beiträge zur Kenntniss der Fossilen Diatomeen Österreich-Ungarns. In: Beiträge zur Paläontologie Österreich-Ungarns und des Orients (von Mojsisovics E, Neumayr N, eds). Universitäts-Buchhandler in Wien, Wien, pp 136-159.

Håkansson H. 2002. A compilation and evaluation of species in the general Stephanodiscus, Cyclostephanos and Cyclotella with a new genus in the family Stephanodiscaceae. Diatom Res 17: 1-139.

Håkansson H, Chepurnov V. 1999. A study of variation in valve morphology of the diatom Cyclotella meneghiniana in monoclonal cultures: effect of auxospore formation and different salinity conditions. Diatom Res 14: 251-272.

Håkansson H, Kling H. 1994. Cyclotella agassizensis nov. sp. and its relatioinship to C. quillensis Bailey and other prairie Cyclotella species. Diatom Res 9: 289-301.

Hasle GR, Fryxell GA. 1970. Diatoms: cleaning and mounting for light and electron microscopy. Trans Am Microsc Soc 89: 469-474.

Helmcke JG, Krieger W. 1954. Diatomeenschalen im elektronenmikroskopischen Bild. Vol 2. J Cramer, Weinheim.

Helmcke JG, Krieger W, Gerloff J. 1974. Diatomeenschalen im elektronenmikroskopischen Bild. Teil VIII. J Cramer, Weinheim.

Houk V, Klee R. 2004. The stelligeroid taxa of the genus $C y$ clotella (Kützing) Brébisson (Bacillariophyceae) and their transfer to the new genus Discostella gen. nov. Dia- 
tom Res 19: 203-228.

Hustedt, F. 1928. Die Kieselalgen Deutschlands, Österreichs und der Schweiz unter Berücksichtigung der übrigen Länder Europas sowie der angrenzenden Meeresgebiete. In: Kryptogamen Flora von Deutschland, Österreich und der Schweiz. (Rabenhorst L, ed). Akademische Verlagsgesellschaft, Leipzig 7, pp 273-464.

Lange CB, Syvertsen EE. 1989. Cyclotella litoralis sp. nov. (Bacillariophyceae), and its relationships to C. striata and C. stylorum. Nova Hedwigia 48: 341-356.

Lee JH. 1995. Additional check-list of marine planktonic algae in the coastal waters of Korea. I. Bacillariophyceae. J Natural Sci, Sangmyung Women's Univ 2: 71-198.

Lee JH, Chung J, Gotoh T. 1995a. Cyclotella orientalis sp. nov. (Bacillariophyceae) from South Korea. Phycol Res 43: 145-149.

Lee JH, Kim HS, Park CW, Chung J. 1994. Morphological study of Cyclotella pseudostelligera Hust. (Bacillariophyceae). Kor J Phycol 9: 111-114.

Lee JH, Lee EH. 1988. A taxonomic study on the genus Cyclotella, Bacillariophyceae, in Korean waters. Kor J Phycol 3: 133-145.

Lee K, Choi JK, Lee JH. 1995b. Taxonomic studies on diatoms in Korea. II. Check-list. Kor J Phycol Suppl 10: 13-89.

Meyer B, Håkansson H. 1996. Morphological variation of $C y$ clotella polymorpha sp. nov. (Bacillariophyceae). Phycologia 35: 64-69.
Prasad AKSK, Nienow JA. 2006. The centric diatom genus Cyclotella, (Stephanodiscaceae: Bacillariophyta) from Florida Bay, USA, with special reference to Cyclotella choctawhatcheeana and Cyclotella desikacharyi, a new marine species related to the Cyclotella striata complex. Phycologia 45: 127-140.

Prasad AKSK, Nienow JA, Livingston RJ. 1990. The genus Cyclotella (Bacillariophyta) in Choctawhatchee Bay, Florida, with special reference to C. striata and C. choctawhatcheeana sp. nov. Phycologia 29: 418-436.

Ross R, Cox EJ, Karayeva NI, Mann DG, Paddock TBB, Simonsen R, Sims PA. 1979. An amended terminology for the siliceous components of the diatom cell. Nova Hedwigia Beiheft 64: 513-533.

Round FE, Sims PA. 1980. The distribution of diatom genera in marine and freshwater environments and some evolutionary considerations. In: Proceedings of the Sixth Symposium on Recent and Fossil Diatoms (Ross R, ed). Otto Koeltz Science Publishers, Koenigstein, pp 301-320.

Takano H. 1976. Scanning electron microscopy of diatoms. I. Cyclotella striata (Kütz.) Grun. Bull Tokai Reg Fish Res Lab 86: 51-57.

Tanaka H. 2007. Taxonomic studies of the genera Cyclotella (Kützing) Brébisson, Discostella Houk et Klee and Puncticulata Håkansson in the family Stephanodiscaceae Glezer et Makarova (Bacillariophyta) in Japan. Bibl Diatomol 53: 1-205. 